\title{
Impact of Remittances on Healthcare Utilisation and Expenditure in Developing Countries: A Systematic Review
}

\author{
Awojobi Oladayo Nathaniel ${ }^{1 *}$ \\ ${ }^{1}$ Department of Social Security, Bonn-Rhein-Sieg, University of Applied Sciences, Grantham Allee, 20, 53757, Sankt Augustin, \\ Germany
}

*Correspondence: Oladayo Nathaniel Awojobi,Email:dawojobi@gmail.com

\begin{abstract}
Background

The poor and low-income earners used remittances to access healthcare services because most of them are not covered by private or government health insurance schemes. The money sent by migrant workers from abroad to their family members, relatives and friends serves as social protection, especially in developing countries where there are no standardised social protection programmes.

Objective

This review assesses the impact of remittances on healthcare utilisation and expenditure in developing countries.

Methods

A systematic search for relevant literature was conducted online for studies published between 2002 and 2018.

\section{Results}

The inclusion criteria of the study were met by 7 out of the 135 studies searched electronically. The studies conducted in Africa, Asia, Europe and Latin America, found that remittances contributed toincreased healthcare access, utilisation and expenditures. However, the degrees of these impacts were limited among the studies except in Armenia, where remittances significantly increased healthcare utilisation.

\section{Conclusion}

Although remittances can not serve as an alternative to formal healthcare insurance schemes, they can serve as a short-term measure in healthcare utilisation in developing countries. It is the responsibility of governments at all levels to formulate health policies that will embrace universal healthcare coverage for all citizens.

Rwanda J Med Health Sci 2019;2(3):304-310.
\end{abstract}

\section{Keywords: Expenditure, healthcare, remittances, utilisation}

\section{Introduction}

Remittances, defined as financial inflow resulting from the cross-border migration of citizens of a country, are the transfer of money and goods sent by migrant workers to their country of birth.[1] The money sent by these migrant workers serves as social protection to their beneficiaries, especially in developing countries where there are no standardised social protection programmes. Policymakers, development experts, and academics have developed a vast interest in the huge amount of money flowing from migrants' host countries to their home countries.[2] Empirical evidence has shown that money sent by international migrants to their home enhances household consumption such as [3] clothing, energy, transport, food, spending on health and miscellaneous services. [4] The non-availability of comprehensive health insurance schemes in most developing countries and the high rate of poverty put people with low-income in vulnerable conditions when they are sick. This is because when they use their low-income for their health upkeep, they are pushed further below the poverty line.[5] Consequently, one mechanism used by low-income earners or the poor to improve their health status is remittance from abroad. Studies have shown that remittances increase healthcare access to the poor and low-income earners in developing countries.[2,6] Other studies have proved that remittances can increase corruption and reduce political demand for change, resulting in a government reducing its social spending. [7-9] This review aims to evaluate the impact of remittances on healthcare utilisation and expenditure of recipients receiving remittances from abroad.

\section{Methods}

\section{Search strategy}

An online search was conducted for relevant literature with the aid of Google search engine, Google Scholar, PubMed and other websites relevant to the study areas. 
Key search terms used include: "remittance," "health," "health utilisation," "healthcare expenditure" and "developing countries." The initial search for selected studies was focused on Asia and Latin America. This was because Asia had around 106 million international migrants, representing $41 \%$ of the global total in 2017 . [10] While Latin America and the Caribbean had 38 million international migrants in different countries of the world as of 2017.[10] An additional search was conducted for studies in Africa because African international migrants were estimated to be 36 million in 2017.[10] The search was limited to English-language articles. Further search for important literature was done on reference lists of included studies. The selected studies were conducted between the period of 2002 to 2018 with most studies conducted in 2002 and 2009.

\section{Study selection and eligible criteria}

Titles and abstracts of all studies searched online were screened to determine their eligibility. Abstracts that reported the use of remittances on healthcare utilisation and expenditure along side other variables were included. In terms of geographical location, I included only studies on remittances and health in developing countries or emerging economies.

This review excluded studies that were written in other languages than the English language as well as studies that did not give in-depth details on remittances and health interface in their findings. Articles that were not research-oriented were excluded. Consequently, online web articles, newspaper reports and policy reports were not included in this review.

\section{Data extraction}

Data were extracted from the included studies of the review by the reviewer using a standardised data extraction tool from JBI SUMARI.[11] The data that were extracted include study citations (author names and date of publication), location, study methods, data collection sources, study population and main outcomes measured.

\section{Data analysis and presentation}

A standardised data collection form was used to extract relevant information from the included studies. Key data information such as citations, geographical setting, methods, data collection methods, year of publication and sample size were extracted and recorded.

Due to the heterogeneity of the included studies, no meta-analysis was included in the study; instead, a narrative synthesis was employed to analyse the data. This was after coding was used to identify salient information. The coding process of this review followed the breaking down of data to identify categories.[12] The initial coding (data reduction) was open coding. The following stage of coding involved linking categories of data identified from the initial coding. The last stage of coding drawed the conclusion and verification, and emerging themes were presented.[12]

\section{Results}

\section{Study selection process}

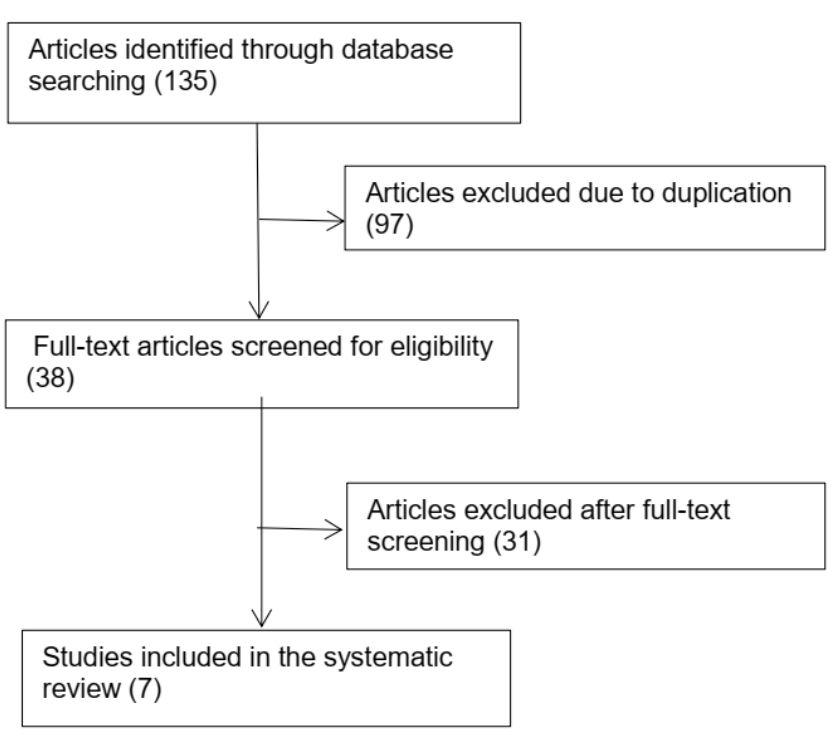

Figure 1: Flow diagram of study selection

Figure 1 presents a summary of the literature search and study selection process. The first search for selected literature produced 135 articles. I screened these articles screened for eligibility through titles and abstracts. The screening excluded 97 articles leaving 38 articles for additional screening. A full screening of abstract and text of the 38 articles that composed of peer-reviewed and grey literature left 31 articles being excluded because they did not meet the inclusion criteria of the systematic review. The remaining 7 articles were included in the final selection process.

\section{Study characteristics}

Table 1 displays the characteristics of the included studies. The included studies were conducted between 2002 and 2018. One of the studies was conducted in Africa (Rwanda), two in Asia (Armenia and Bangladesh), one in Europe (Albania) and three in Latin America (Ecuador and Mexico). In terms of methods, four studies used quantitative methods and the remaining three studies employed a mixed-methods approach. Most of the data of the included studies were sourced from government official documents and household surveys. Health variables measured by the studies include healthcare, health expenditure, healthcare utilisation and access to quality healthcare. As for article types, six were peer-reviewed articles while the remaining one is a discussion paper. 
Table 1. Characteristics of included studies

\begin{tabular}{|c|c|c|c|c|c|c|c|}
\hline Study & $\begin{array}{l}\text { Year of } \\
\text { publication }\end{array}$ & Country & Methods & Data collection source & Sample size & $\begin{array}{l}\text { Outcome } \\
\text { measured }\end{array}$ & $\begin{array}{l}\text { Type of } \\
\text { article }\end{array}$ \\
\hline $\begin{array}{l}\text { Al Kabir et } \\
\text { al.[16] }\end{array}$ & 2018 & Bangladesh & Quantitative & $\begin{array}{l}\text { Data on total } \\
\text { remittance inflow (\$US), } \\
\text { and life expectancy } \\
\text { at birth (as a proxy } \\
\text { of health care)are } \\
\text { taken from World } \\
\text { Development Indicator }\end{array}$ & $\mathrm{N} / \mathrm{A}$ & $\begin{array}{l}\text { Healthcare } \\
\text { utilisation }\end{array}$ & $\begin{array}{l}\text { Peer- } \\
\text { reviewed }\end{array}$ \\
\hline $\begin{array}{l}\text { Amuedo- } \\
\text { Dorantes and } \\
\text { Pozo[18] }\end{array}$ & 2009 & Mexico & Quantitative & $\begin{array}{l}\text { (WDI) } \\
\text { A nationally } \\
\text { representative survey }\end{array}$ & $\mathrm{N} / \mathrm{A}$ & $\begin{array}{l}\text { Healthcare } \\
\text { expenditure }\end{array}$ & $\begin{array}{l}\text { Discussion } \\
\text { paper }\end{array}$ \\
\hline Frank et al.[15] & 2009 & Mexico & Mixed & $\begin{array}{l}\text { Data were from a } 2006 \\
\text { survey of } 2 \text { localities in } \\
\text { the municipal city of } \\
\text { Tepoztla' n, Morelos }\end{array}$ & $\begin{array}{l}2,044 \\
\text { households }\end{array}$ & $\begin{array}{l}\text { Healthcare } \\
\text { utilisation, } \\
\text { health } \\
\text { expenditure }\end{array}$ & $\begin{array}{l}\text { Peer- } \\
\text { reviewed }\end{array}$ \\
\hline Kalaj[6] & 2015 & Albania & Quantitative & Household survey data & $\mathrm{N} / \mathrm{A}$ & $\begin{array}{l}\text { Expenditure } \\
\text { for medicines } \\
\text { and other } \\
\text { health services }\end{array}$ & $\begin{array}{l}\text { Peer- } \\
\text { reviewed }\end{array}$ \\
\hline $\begin{array}{l}\text { López-Cevallos } \\
\text { and Chi[2] }\end{array}$ & 2012 & Ecuador & Mixed & $\begin{array}{l}\text { Using data from } \\
\text { the } 2004 \text { National } \\
\text { Demographic and } \\
\text { Maternal \& Child Health } \\
\text { Survey }\end{array}$ & $\begin{array}{l}\text { (a) } \\
\text { (b) } 21,797 \\
\text { households }\end{array}$ & $\begin{array}{l}\text { Healthcare } \\
\text { utilisation, } \\
\text { sexual and } \\
\text { reproductive } \\
\text { health }\end{array}$ & $\begin{array}{l}\text { Peer } \\
\text { reviewed }\end{array}$ \\
\hline Murrugarra[17] & 2002 & Armenia & Quantitative & $\begin{array}{l}\text { Integrated Living } \\
\text { Standard Survey }\end{array}$ & $\begin{array}{l}3,600 \\
\text { households }\end{array}$ & $\begin{array}{l}\text { Healthcare } \\
\text { utilisation }\end{array}$ & $\begin{array}{l}\text { Peer- } \\
\text { reviewed }\end{array}$ \\
\hline Rubyutsa[3] & 2002 & Rwanda & Mixed & $\begin{array}{l}\text { Interview, data from the } \\
\text { Department of Statistics } \\
\text { at the National Bank of } \\
\text { Rwanda }\end{array}$ & $\mathrm{N} / \mathrm{A}$ & $\begin{array}{l}\text { Healthcare } \\
\text { accessibility }\end{array}$ & $\begin{array}{l}\text { Peer- } \\
\text { reviewed }\end{array}$ \\
\hline
\end{tabular}

Note: N/A means not available

Impact of remittances on healthcare utilisation and expenditure

For a proper understanding of this review, healthcare utilisation is defined as the "quantification or description of the use of services by persons for the purpose of preventing and curing health problems, promoting maintenance of health and well-being".[13] While healthcare expenditure is the "final consumption of health care goods and services (i.e. current health expenditure) including personal health care (curative care, rehabilitative care, long-term care, ancillary services and medical goods) and collective services (prevention and public health services as well as health administration)".[14]

\section{Healthcare utilisation}

Out of the 7 studies, five reported on the impact of remittances on healthcare accessibility/utilisation. [2,3,15-17] In Armenia, data from an Integrated Living Standard Survey showed that remittances responded to health needs.[17] However, remittances did not have a significant impact on healthcare utilisation because social assistance from the government significantly displaced remittances in healthcare utilisation.[17] In Bangladesh, remittance and health interface showed a bidirectional causality. In the long run, an increase in remittances allowed households to take quality healthcare if needed. [16] In contrast, in the short run, there was no relationship between remittances and healthcare utilisation.

In Ecuador, data from the 2004 National Demographic and Maternal \& Child Health Survey and multilevel multivariate analysis of the relationship between remittances and healthcare utilisation showed that a household having a migrant abroad was positively associated with using an antiparasitic drug.[2] Aside from the use of the antiparasitic drug, household receiving remittances always visit medical centres for preventive cure. The study also found that low-income earners or the poor in Ecuador are the ones that predominantly use remittances for healthcare utilisation. However, 
most low-income earners used remittances to offset their daily health needs and not on long-term healthcare. In Mexico, households that have migrants in the United States and receive remittances used them to gain access to healthcare services. [15] People covered by the government insurance programme with limited coverage used remittances to access services not provided by the Mexican government insurance programme.[15]
In Rwanda, remittance data from the Department of Statistics at the National Bank of Rwanda revealed that people used remittances for the improvement of family lives and healthcare accessibility and utilisation. [3] Table 2 reviews the impact of remittances on healthcare utilisation.

\section{Table 2. Review of effects of remittances on healthcare utilisation}

\begin{tabular}{|c|c|c|c|c|c|c|}
\hline Country & study & Study design & Population & $\begin{array}{l}\text { Main } \\
\text { outcomes }\end{array}$ & Results & Impact \\
\hline Armenia & $\begin{array}{l}\text { Murrugarra, } \\
{[17]}\end{array}$ & Censored model & $\begin{array}{l}3,600 \\
\text { households } \\
\text { receiving } \\
\text { remittances }\end{array}$ & $\begin{array}{l}\text { Healthcare } \\
\text { demand }\end{array}$ & $\begin{array}{l}1,000 \text { Armenia Drams (ADM) in } \\
\text { remittances (approximately US } \$ 2 \text { ) } \\
\text { enhanced healthcare utilisation rates in } \\
\text { a very small, but significant increase. }\end{array}$ & Positive \\
\hline Bangladesh & $\begin{array}{l}\text { Al Kabir et } \\
\text { al.[16] }\end{array}$ & Time series & $\begin{array}{l}\text { Individuals } \\
\text { that have } \\
\text { received } \\
\text { remittances }\end{array}$ & $\begin{array}{l}\text { Healthcare } \\
\text { utilisation }\end{array}$ & $\begin{array}{l}\text { In the long run there was positive } \\
\text { relationship between remittance } \\
\text { and health improvement. While in } \\
\text { the short run there was no positive } \\
\text { relationship between remittances and } \\
\text { health improvement. }\end{array}$ & Mixed \\
\hline Ecuador & $\begin{array}{l}\text { López- } \\
\text { Cevallos and } \\
\text { Chi[2] }\end{array}$ & $\begin{array}{l}\text { Cross- } \\
\text { sectional }\end{array}$ & $\begin{array}{l}10,813 \\
\text { households } \\
\text { that have } \\
\text { received } \\
\text { remittances }\end{array}$ & $\begin{array}{l}\text { Healthcare } \\
\text { utilization }\end{array}$ & $\begin{array}{l}\text { Remittances improved the use of } \\
\text { antiparasitic drug (odds tatio) }(\mathrm{OR}= \\
1.46,95 \% \mathrm{CI}=1.23-1.73 \text {; } \mathrm{OR}= \\
1.34,95 \% \mathrm{CI}=1.16-1.55) \text { "after } \\
\text { adjusting for predisposing, enabling, } \\
\text { and need factors" }\end{array}$ & Positive \\
\hline Mexico & $\begin{array}{l}\text { Frank et } \\
\text { al.[15] }\end{array}$ & $\begin{array}{l}\text { Multinomial } \\
\text { logistic } \\
\text { regression }\end{array}$ & $\begin{array}{l}\text { Remittance } \\
\text { recipients }\end{array}$ & $\begin{array}{l}\text { Healthcare } \\
\text { utilisation }\end{array}$ & $\begin{array}{l}\text { Of those households that had } \\
\text { received remittances, over twice as } \\
\text { many had spent remittances on health } \\
\text { than had not }(7 \% \text { versus } 3 \%) \text {. }\end{array}$ & Positive \\
\hline Rwanda & Rubyutsa[3] & $\mathrm{N} / \mathrm{A}$ & $\begin{array}{l}\text { Members } \\
\text { of Diaspora } \\
\text { community }\end{array}$ & $\begin{array}{l}\text { Healthcare } \\
\text { accessibility }\end{array}$ & $\begin{array}{l}\text { Reason for remittance include } \\
\text { healthcare issues }\end{array}$ & Not clear \\
\hline
\end{tabular}

\section{Health expenditure}

Three studies have reported the impact of remittances on health expenditure. $[6,15,18]$ Table 3 shows the review of the effects of remittances on health expenditure in Albania, an analysis of the impact of remittances on health expenditures showed that households receiving remittances increased their health expenditures on drugs and other health-related services such as medical visits and laboratory services.[6] The impact was significant for households in rural areas because the total expenditures on drugs increased by approximately \$86.27. The findings of the study reveal that remittances have a positive impact on the expenditure for medical visits and laboratory services. [6]
In Mexico, data from a nationally representative survey carried out by the Mexican statistical institute showed that remittances increased health expenditures for both low-income households and rich households.[18] High-income households receiving $\$ 5.25$ increment in remittance increased expenditures on health by $\$ 0.37$. [18] A similar increment in low-income households showed that spending on health rose by $\$ 0.21$.[18] In Mexico, the health status of remittance beneficiaries was not significantly related to remittances and expenditure on healthcare.[15] 
Table 3. Review of effects of Remittances on health care expenditures

\begin{tabular}{lllllll}
\hline Country & Study & Study design & Population & $\begin{array}{l}\text { Main } \\
\text { outcomes }\end{array}$ & Results & Impact \\
\hline Albania & Kalaj[6] & $\begin{array}{l}\text { Propensity } \\
\text { score } \\
\text { matching }\end{array}$ & $\begin{array}{l}\text { Households } \\
\text { with migrants } \\
\text { abroad }\end{array}$ & $\begin{array}{l}\text { Healthcare } \\
\text { expenditure }\end{array}$ & $\begin{array}{l}\text { Remittances have a positive } \\
\text { and statistically significant } \\
\text { impact on health expenditures }\end{array}$ & Positive \\
Mexico & $\begin{array}{l}\text { Amuedo- } \\
\text { Dorantes and } \\
\text { Pozo[18] }\end{array}$ & N/A & $\begin{array}{l}\text { Remittance } \\
\text { recipients }\end{array}$ & $\begin{array}{l}\text { Healthcare } \\
\text { expenditure }\end{array}$ & $\begin{array}{l}\text { \$86.27 rise in remittance } \\
\text { from abroad increases } \\
\text { healthcare expenditures }\end{array}$ & Positive \\
bexico & Frank et al.[15] & $\begin{array}{l}\text { Multinomial } \\
\text { logistic } \\
\text { regression }\end{array}$ & $\begin{array}{l}\text { Remittance } \\
\text { recipients }\end{array}$ & $\begin{array}{l}\text { Healthcare } \\
\text { expenditure }\end{array}$ & $\begin{array}{l}\text { Amount of remittances was } \\
\text { not significantly correlated } \\
\text { with expenditure on } \\
\text { healthcare }\end{array}$ & Negative \\
& & & & & &
\end{tabular}

\section{Discussion}

A systematic review methodology was used to assess the impact of international remittances on healthcare utilisation and expenditure in developing countries. Remittance has come a long way in assisting low-income earners in increasing access to healthcare services. Findings from this review have shown that remittance plays a vital role in healthcare utilisation and expenditure to recipients of remittances from abroad.

In most developing countries where there are no universal health insurance schemes, the poor have difficulty accessing healthcare services because of their socioeconomic status. For instance, in Kenya, poverty reduced the probability of infants and children aged 1-14 from visiting modern healthcare facilities.[19] Poverty is a barrier to the poor in accessing healthcare services in developing countries.[20] Where there are no social health insurance schemes for low-income earners, remittances serve as a substitute for those that have international migrants that are sending money to them. $[2,17]$

Findings from this review showed that remittances led to healthcare access and utilisation among remittance households. In Armenia, Bangladesh, Ecuador, Mexico and Rwanda, households receiving remittances could utilise healthcare services. However, most of the studies did not show the level of healthcare utilisation and accessibility among the recipients. These findings aligned with the findings of Amakom and Iheoma.[21] In their study, an increase in remittance was responsible for the increase in healthcare utilisation.

In the case of health expenditure, an increase in remittances corresponded with an increase in healthcare expenditures among recipient households. The findings from this review showed that remittance increased household expenditure in Albania and Mexico. While in Albania there was a significant impact between remittances and health expenditures; in Mexico, the studies assessed did not show the level of impact. These findings are aligned with the findings of AmuedoDorantes and Pozo)[22] in Mexico. The review revealed that healthcare expenditures increased in response to an increase in remittances. In addition, primary healthcare expenditures were higher in households with high remittance inflow. Such households spent between $5 \%$ and $9 \%$ remittance receipts on primary healthcare services.[22]

From the findings of this review, it has been established that the poor are the ones that predominantly use remittances for healthcare services. This is because of the lack of formal insurance coverage to protect them against health shocks. Remittance serves as social protection to the poor and from the evidence presented in this review, remittance is a social safety net in the absence of a formal social insurance programme.

Those that have families in developed countries and are receiving remittances from abroad feel protected against health shocks. In the contrary, those who do not have families abroad and are not receiving remittances or social assistance, find themselves in precarious conditions when they fall sick. Therefore, governments in developing countries should establish universal healthcare coverage that will protect both the poor and rich against health shocks, help to reduce health inequality among the population and boost the economy.

This review has some limitations: it only analysed studies that were published in English Language, whereas, there are quality studies in other languages that assessed the impact of remittances on healthcare utilisation and expenditure. In addition, some included studies lacked adequate data and some of their findings are too clumsy to understand for analysis. Most of the studies did not expatiate on the the degree of the impact of remittances on health outcomes. 


\section{Conclusion}

This review assesses the impact of remittances on healthcare utilisation and expenditure in developing countries. The studies included in the review have established that remittances play a vital role in allowing the poor and low-income earners to access healthcare services as well as increasing expenditure on healthcare goods and services. Those in rural areas used remittances for healthcare services to a larger extent than those living in urban areas.

Remittances cannot serve as a substitute or alternative to formal healthcare insurance schemes, but they complement private or government own insurance programmes. While remittances serve only a few households in accessing healthcare services, it is the responsibility of the governments to design and implement universal healthcare coverage that will serve all individuals.

\section{Authors' contribution}

ONA designed the study, performed the selection of the included studies, conducted data analysis and approved the final manuscript.

\section{Conflict of interest}

The author of this study declared no conflict of interest.

This article is published open access under the Creative Commons Attribution-NonCommercialNoDerivatives (CC BY-NC-ND4.0). People can copy and redistribute the article only for noncommercial purposes and as long as they give appropriate credit to the authors. They cannot distribute any modified material obtained by remixing, transforming or building upon this article. See https://creativecommons.org/ licenses/by-nc-nd/4.0/

\section{References}

1. Thapa S, Acharya S. Remittances and Household Expenditure in Nepal: Evidence from CrossSection Data. Economies. 2017 Jun;5(2):16.

2. López-Cevallos DF, Chi C. Migration, remittances, and health care utilization in Ecuador. RevistaPanamericana de SaludPública. 2012 Jan;31(1):9-16.

3. Rubyutsa J. The Role of Remittance in Development: The Case of Rwandan Diaspora' Remittances. Rwanda Journal. 2012;26(1):120-32.

4. OECD. Expenditure. OECD; 2013.

5. Woldemichael A, Gurara DZ, Shimeles A. Community-Based Health Insurance and Out-ofPocket Healthcare Spending in Africa: Evidence from Rwanda. Institute for the Study of Labor. 2016;2-37.
6. Kalaj EH. A Micro-level Analysis of the Effect of Remittances on Health Expenditures: Evidence from Albania. Mediterranean Journal of Social Sciences. 2015 Jan 1;6(1):665-73.

7. Ahmed FZ. Remittances Deteriorate Governance. The Review of Economics and Statistics. 2012 Oct 10;95(4):1166-82.

8. Ebeke CH. Do Remittances Lead to a Public Moral Hazard in Developing Countries? An Empirical Investigation. The Journal of Development Studies. 2012 Aug 1;48(8):1009-25.

9. Doyle D. Remittances and Social Spending. American Political Science Review. 2015 Nov;109(4):785-802.

10. United Nations, Department of Economic and Social Affairs, Population Division. Population Facts: The world counted 258 million international migrants in 2017, representing 3.4 per cent of global population [Internet]. UN; 2017 [cited 2019 Jul 21]. Available from: https://www.un.org/en/ development/desa/population/publications/ pdf/popfacts/PopFacts_2017-5.pdf

11. Aromataris E, Munn Z. Chapter 1: JBI Systematic Reviews. In: Aromataris E, Munn Z (Editors). Joanna Briggs Institute Reviewer's Manual [Internet]. The Joanna Briggs Institute. 2017 [cited 2019 May 4]. Available from: https:// wiki.joannabriggs.org/display/MANUAL/ Chapter+1\%3A+JBI+Systematic+Reviews

12. Strauss A, Corbin JM. Basics of qualitative research: Grounded theory procedures and techniques. Thousand Oaks, CA, US: Sage Publications, Inc; 1990. 270 p. (Basics of qualitative research: Grounded theory procedures and techniques).

13. Carrasquillo O. Health Care Utilization. In: Gellman MD, Turner JR, editors. Encyclopedia of Behavioral Medicine [Internet]. New York, NY: Springer New York; 2013 [cited 2019 Jul 21]. p. 909-10. Available from: https://doi. org/10.1007/978-1-4419-1005-9_885

14. OECD. Health spending (indicator) [Internet]. theOECD. 2019 [cited 2019 Jul 21]. Available from: http://data.oecd.org/healthres/healthspending.htm

15. Frank R, Palma-Coca O, Rauda-Esquivel J, OlaizFernández G, Díaz-Olavarrieta C, AcevedoGarcía D. The Relationship Between Remittances and Health Care Provision in Mexico. American Journal of Public Health. 2009;99(7):1227-31. 
16. Al Kabir F, Khan F, Amin SB. Impact of Remittance on Enrollment and Health Care: The Case of Bangladesh. World Review of Business Research. 2018;8(2):56-66.

17. Murrugarra E. Public Transfers and Migrants' Remittances: Evidence from the Recent Armenian Experience. World Bank Economists' Forum. 2002;(2):25-47.

18. Amuedo-Dorantes C, Pozo S. New evidence on the role of remittances on healthcare expenditures by Mexican households. Institute for the Study of Labor. 2009;9(1):69-98.

19. Awiti JO. Poverty and health care demand in Kenya. BMC Health Serv Res. 2014 Dec;14(1):560.

20. Peters DH, Garg A, Bloom G, Walker DG, Brieger WR, Rahman MH. Poverty and Access to
Health Care in Developing Countries. New York Academy of Sciences. 2008;161-9.

21. Amakom U, Iheoma CG. Impact of Migrant Remittances on Health and Education Outcomes in Sub-Saharan Africa. IOSR Journal of Humanities and Social Science. 2014;19(8):33-44.

22. AmuedoDorantes C, Pozo S, Sainz T. Remittances and healthcare expenditure patterns of populations in origin communities: evidence from Mexico [Internet]. Washington, DC: IDB; 2007 [cited 2019 Jan 17]. Available from: http://www.iadb. org/intal/aplicaciones/uploads/publicaciones/i_ INTALITD_WP_25_2007_AmuedoDorantes_ Sainz_Pozo.pdf 